\title{
A convergent approach for the synthesis of fluorinated sphingosine analogues
}

\author{
Harriet Teare, ${ }^{\mathrm{a}}$ Florian Huguet, ${ }^{\mathrm{a}}$ Matthew Tredwell, ${ }^{\mathrm{a}}$ Sébastien Thibaudeau, ${ }^{\mathrm{a}}$ Sajinder \\ Luthra, ${ }^{b}$ and Véronique Gouverneur ${ }^{a}$ * \\ ${ }^{a}$ University of Oxford, Chemistry Research Laboratory, 12 Mansfield Road, \\ Oxford OX1 3TA (UK) \\ ${ }^{b}$ Hammersmith Imanet Ltd (part of GE Healthcare), Hammersmith Hospital, Du Cane Road, \\ London, UK W12 0NN \\ E-mail: veronique.gouverneur@chem.ox.ac.uk
}

Dedicated to Professor Alain Krief on the occasion of his $65^{\text {th }}$ birthday

\begin{abstract}
An improved route to a fluorinated analogue of sphingosine has been developed starting from Garner's aldehyde with two cross-metathesis couplings and an electrophilic fluorodesilylation as the key steps. This approach eliminates the problem of double bond transposition encountered with strategies relying on the nucleophilic fluorinating reagent DAST and supplies the target compound as well as a fluorinated intermediate amenable to functional variations at three sites.
\end{abstract}

Keywords: Allylsilane, fluorine, sphingosine, metathesis

\section{Introduction}

Sphingomyelin 1, an abundant membrane phospholipid, is metabolized into lipid mediators such as ceramide 2, sphingosine 3, and sphingosine-1-phosphate 4 (S1P). The concept that sphingolipid metabolism is an important source of signaling lipids has gained considerable acceptance. ${ }^{1}$ The importance of this metabolic pathway is underscored by its impact on cell death, stress responses and animal development in unicellular and multicellular eukaryotes. 


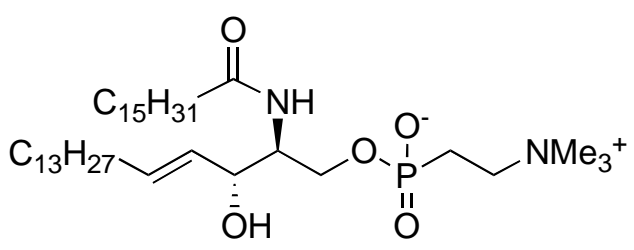

sphingomyelin 1<smiles>[13CH3][13CH2]/C=C/[C@H](O)[C@@H](N)CO</smiles>

sphingosine 3

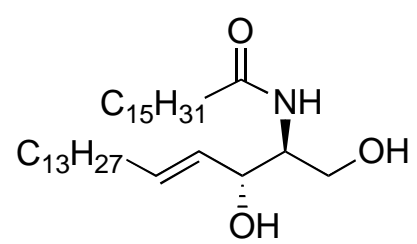

ceramide 2<smiles>[13CH3]/C=C/[C@H](O)[C@@H](N)CO[O+](O)O</smiles>

sphingosine-1-phosphate 4

Figure 1. Signaling lipids derived from sphingomyelin metabolism.

One of these metabolites, sphingosine-1-phosphate $\mathbf{4}$ acts as an extracellular mediator by activating a family of protein-coupled receptors (S1PR1-5). ${ }^{1}$ The generality of sphingosine-1phosphate signaling is supported by recent findings that S1PRs are required for a multitude of physiological processes, including heart and vascular development, angiogenesis, and immune cell trafficking. ${ }^{2}$ These remarkable findings on the role of sphingolipids led to the development of numerous protocols for their syntheses. ${ }^{3}$ Sphingolipids all feature a common structural motif, which consists of a non-racemic chiral 4,5-unsaturated 2-amino 1,3-diol biosynthetically derived from L-serine. Structural variations occur with the substituents attached to the primary alcohol and the amino group. Metabolites with additional modifications on the main carbon chain have also been identified. Many diversity-oriented approaches have been devised and validated for the synthesis of sphingolipids. However, convergent synthetic routes to sphingolipid analogues are still in demand to further probe the physiological and pathological significance of sphingolipid metabolism. Several groups have prepared fluorosphingosine derivatives following a synthetic scheme based on the nucleophilic fluorination of the corresponding allylic alcohol with DAST. ${ }^{4}$ However, this approach suffers from poor control over product outcome, due to double bond transposition upon fluorination, along with the formation of non-fluorinated side-products. In this paper, we report a novel convergent approach to fluorinated sphingosine that allows structural variations at three sites.



Fluorinated analogue of sphingosine 5

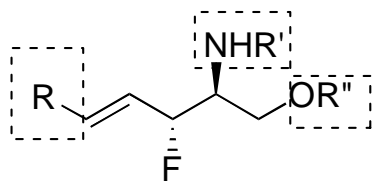

Three sites for structural variation

Figure 2. Fluorinated analogues of sphingolipids 


\section{Results and Discussion}

One of the most convergent approaches for the preparation of non-fluorinated sphingosine analogues relies on a retrosynthetic scheme in which the main carbon chain is introduced via a highly stereoselective olefin cross metathesis reaction involving an orthogonally protected precursor of general structure $\mathbf{A}^{5}$ A similar strategy for the preparation of the corresponding fluorinated analogues is highly desirable and will necessitate access to intermediate $\mathbf{B}$ possessing a terminal allylic fluoride in addition to the protected amine and primary alcohol. We have previously reported that both the homometathesis and the cross-metathesis of terminal allylic fluorides with structurally diverse olefinic partners is feasible. ${ }^{6}$ These results prompted us to prepare a representative terminal allylic fluoride fitting the structural requirements of $\mathbf{B}$ and evaluate its use as a precursor to various fluorinated analogues of sphingosine by investigating the key cross-metathesis coupling.<smiles>[R]C=C[C@@H](O)[C@H](C[R])N[R]</smiles>
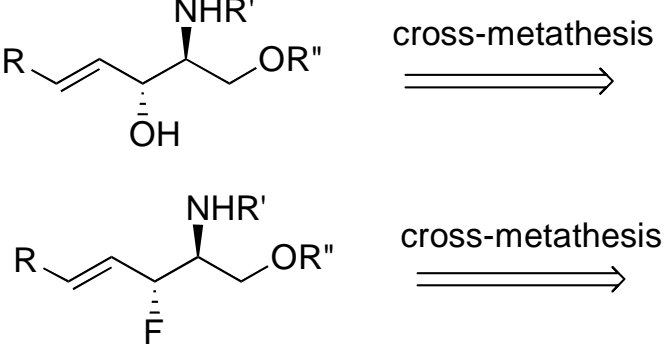

cross-metathesis



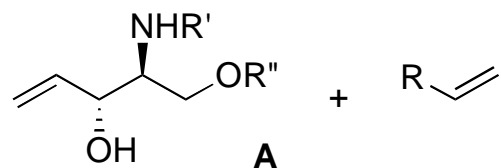

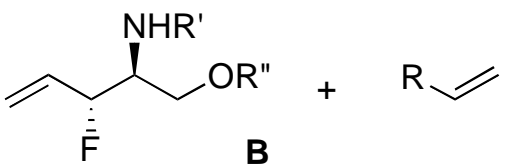

Scheme 1. Retrosynthetic analysis allowing for structural diversity.

Due to the difficulties encountered by Herdewijn et al. with the preparation of fluorinated analogues of sphingosine by nucleophilic fluorination of the corresponding allylic alcohol, ${ }^{4 a, b}$ we designed an electrophilic fluorination of the corresponding allylsilane as a route for $\mathbf{B}$. The fluorodesilylation of allysilanes, a reaction discovered in our group, takes place according to an $\mathrm{S}_{\mathrm{E}} 2$ ' mechanism with clean transposition of the double bond, allowing for the desired allylic fluorides to be formed in good to excellent isolated yields. ${ }^{7}$ This route could overcome the problem of product selectivity encountered with protocols based on DAST-mediated nucleophilic fluorination. The allylsilane 7 was selected to access the protected allylic fluoride 6. This intermediate can be prepared from the (S)-Garner's aldehyde 8, a configurationally stable $(S)$-serinal equivalent (Scheme 2). ${ }^{8}$ Upon fluorodesilylation, allylsilane 7 should lead to compound 6, the key intermediate necessary for further functionalisation of the terminal alkene by cross-metathesis. 


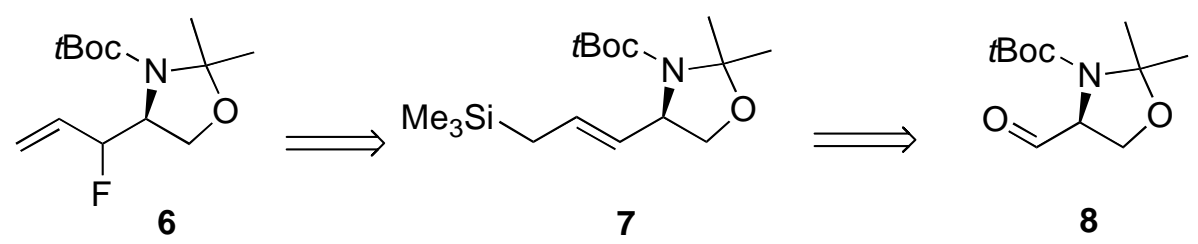

Scheme 2. Retrosynthesis of compound 6.

Garner's aldehyde 8 was easily prepared following the literature procedure. ${ }^{11}$ The yield from L-serine was $45 \%$ with an $[\alpha]_{\mathrm{D}}=-92^{\circ}\left(\mathrm{c}=1.00, \mathrm{CHCl}_{3}\right)$ matching literature data. Direct conversion of aldehyde 8 into allylsilane 7 was first attempted using the Wittig-Seyferth reaction. ${ }^{9}$ Using freshly prepared $\beta$-trimethylsilylethyltriphenylphosphonium iodide, ${ }^{10}$ the reactions consistently led to the formation of complex reaction mixtures which were difficult to purify and the desired allysilane 7 was isolated in a very low yield of $12 \%$. Moreover, the product could never be obtained analytically pure rendering the stereochemical assignment of the double bond ambiguous. The difficulties encountered with this reaction encouraged us to develop an alternative route to 7 . We chose a two-step process based on a Wittig methylenation followed by a cross-metathesis coupling with allyltrimethylsilane. Wittig methylenation of Garner's aldehyde can be problematic due to partial or total racemisation. Following the procedure of McKillop and Taylor, we carried out the olefination under salt-free Wittig conditions using methyltriphenylphosphonium bromide and potassium bis(trimethylsilyl)amide [KHMDS] as the base and obtained compound 9 in $90 \%$ yield and high optical purity (consistent with literature data) (Scheme 3). ${ }^{11}$

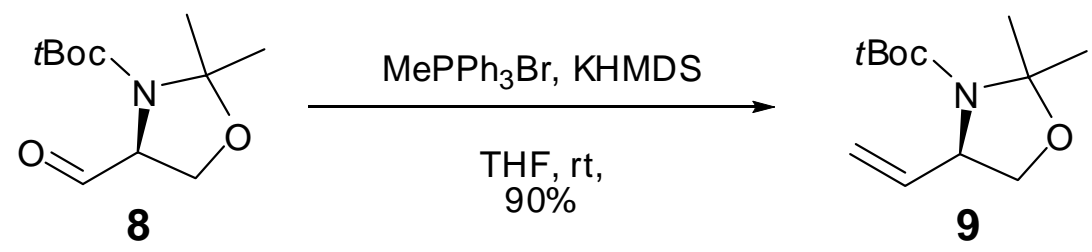

Scheme 3. Wittig-methylenation of Garner's aldehyde.

With compound 9 in hand, the cross-metathesis coupling with allyltrimethylsilane was examined. This transformation, which was carried out in dichloromethane using three equivalents of allyltrimethylsilane, required extensive optimisation to succeed (Scheme 4, Table 1). When no additive was used, mainly starting material was recovered using $10 \mathrm{~mol} \%$ of either the Grubbs' catalyst $\mathbf{1 0}^{12}$ or the Hoveyda's catalyst $\mathbf{1 1}^{13}$ (entries 1 and 2, Table 1). The addition of $20 \mathrm{~mol} \%$ of $\mathrm{CuCl}$ was not beneficial as only a trace of the desired product was detected under these modified reaction conditions (entry 3, Table 1) ${ }^{14}$ However, the joint use of $10 \mathrm{~mol} \%$ of Grubbs catalyst $\mathbf{1 0}$ with $30 \mathrm{~mol} \%$ of $\mathrm{Ti}(\mathrm{OiPr})_{4}$ as a binary catalytic system allowed for the coupling of $\mathbf{9}$ and allyltrimethylsilane to occur at $42^{\circ} \mathrm{C}$ affording the desired 
allylsilane 7 in $65 \%$ isolated yield as an inseparable $6 / 1$ mixture of $E / Z$ isomers (entry 4 , Table 1 ). This result further illustrates the value of this binary catalytic system developed by Furstner and co-workers. $^{15}$ The addition of a stoichiometric amount of $\mathrm{Ti}(\mathrm{OiPr})_{4}$ was detrimental as 7 was obtained in only $29 \%$ yield along with unreacted starting material.
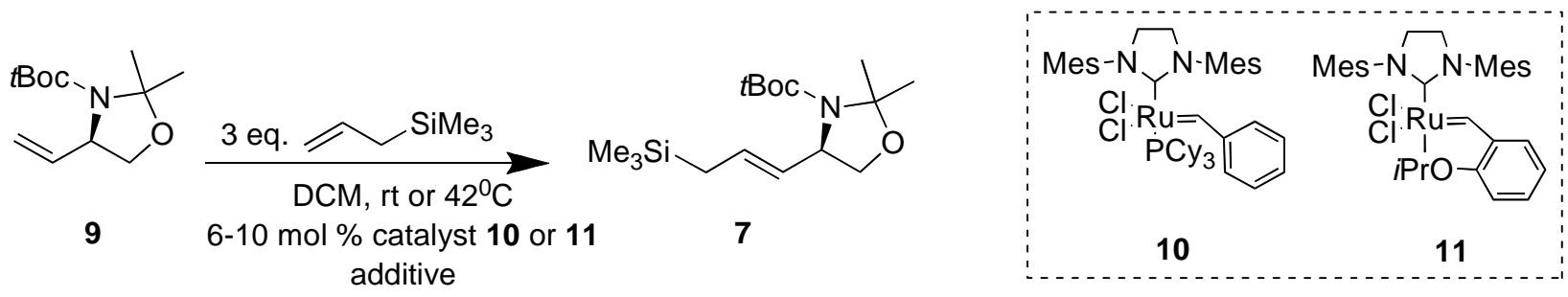

Mes $=2,4,6$-trimethylphenyl

Scheme 4. Cross-metathesis of 9 with allyltrimethylsilane.

Table 1. Optimization studies for the cross-coupling of 9

\begin{tabular}{|l|l|l|l|l|l|l|}
\hline Entry & $\begin{array}{l}\text { Catalyst } \\
(\mathrm{mol} \%)\end{array}$ & $\begin{array}{l}\text { Additive } \\
(\mathrm{mol} \%)\end{array}$ & Temp $\left({ }^{0} \mathrm{C}\right)$ & $\begin{array}{l}\text { Recovered } \\
9(\%)\end{array}$ & $\begin{array}{l}\text { Yield } \\
(\%)\end{array}$ & E/Z ratio \\
\hline 1 & $10(10)$ & - & 42 & 85 & $<5$ & - \\
\hline 2 & $11(10)$ & - & $\mathrm{Rt}$ & 90 & $<5$ & - \\
\hline 3 & $10(10)$ & $\mathrm{CuCl}(20)$ & 42 & 85 & $<5$ & - \\
\hline $\mathbf{4}$ & $\mathbf{1 0}(\mathbf{1 0})$ & $\begin{array}{l}\mathbf{T i}(\mathrm{OiPr})_{4} \\
(\mathbf{3 0})\end{array}$ & $\mathbf{4 2}$ & - & $\mathbf{6 5}$ & $\mathbf{6}$ \\
\hline 5 & $11(10)$ & $\begin{array}{l}\mathrm{Ti}(\mathrm{OiPr})_{4} \\
(30)\end{array}$ & $\mathrm{Rt}$ & 73 & 6 & $9 / 1$ \\
\hline 6 & $10(10)$ & $\begin{array}{l}\mathrm{Ti}(\mathrm{OiPr})_{4} \\
(100)\end{array}$ & 42 & 53 & 29 & $6 / 1$ \\
\hline 7 & $10(6)$ & $\begin{array}{l}\mathrm{Ti}(\mathrm{OiPr})_{4} \\
(30)\end{array}$ & 42 & 79 & 16 & $6 / 1$ \\
\hline
\end{tabular}

The fluorodesilylation of compound 7 was carried out at room temperature in acetonitrile in the presence of one equivalent of the electrophilic fluorinating reagent Selectfluor ${ }^{\mathrm{TM}}$ [1chloromethyl-4-fluoro-1,2-diazoniabicyclo[2.2.2] octane bis(tetrafluoroborate], ${ }^{16}$ following the procedure developed in our laboratory (Scheme 5). ${ }^{7}$ The starting material was totally consumed after 24 hours with concomitant formation of products of very different polarity as judged by thin layer chromatography. Purification by silica gel chromatography afforded $17 \%$ of the desired fluorinated product 6 and 35\% of a much more polar fluorinated compound identified unambiguously as the partially deprotected allylic fluoride 12. Gratifyingly, upon extended reaction time (48h) and with 2.2 eq of Selectfluor, compound 12 was obtained as a mixture of 
two diastereomers [ratio $~ 1 / 1$ ] in $62 \%$ yield with no trace of 6 . The two diastereomers can be separated by careful silica gel chromatography. Upon purification, anti-12 was recovered analytically pure in larger amount than syn-12. Compounds syn-12 and anti-12 are versatile precursors for the preparation of various analogues differently functionalised through the primary alcohol, the amino group or the double bond. This result suggests that Selectfluor mediates two processes one-pot, the desired electrophilic fluorination and the partial deprotection of the aminoalcohol leaving the N-Boc group intact. Protecting-group removal with Selectfluor has already been reported in the literature with the mild cleavage of THP ethers and dithianes. ${ }^{17}$ For the deprotection of dithianes into the corresponding aldehydes, it has been suggested that Selectfluor acts as a Lewis acid although alternative mechanistic pathways are possible including oxidation. Mechanistically, the electrophilic fluorodesilylation of compound 7 led to the formation of compound 6 along with one equivalent of $\mathrm{FSiMe}_{3}$ and $\mathrm{BF}_{3}$ if one asumes that $\mathrm{BF}_{4}{ }^{-}$participates in the desilylation process. It is possible that the active species triggering the partial deprotection is $\mathrm{BF}_{3}$ weakly coordinated to acetonitrile. ${ }^{18}$ We carried out a control experiment to assess whether or not the fluorinating reagent itself could mediate the deprotection. Treating compound 9 with one equivalent of Selectfluor in acetonitrile, no reaction took place supporting our hypothesis that it is the side-products resulting from the fluorodesilylation of the allylsilane $\mathbf{7}$ which is responsible for its concomitant partial deprotection. In the light of this mechanistic hypothesis, further optimization work revealed that when compound 7 was reacted for 48 hours at room temperature in acetonitrile with Selecfluor ( 1 eq.) in the presence of two equivalents of $\mathrm{NaHCO}_{3}$, no deprotection took place. The only product formed under these conditions is the fully protected fluorinated compound 6 isolated in $72 \%$ yield. This compound was formed as an inseparable mixture of two diastereomers in a ratio of $\sim 1: 1$. The two separable partially deprotected stereoisomers were identified as the anti-12 and syn-12 product based on comparison of their coupling constants and chemical shifts with data available in the literature for the structurally related fluorinated compounds (anti $12{ }^{3} J_{\mathrm{HF}}=20$ [lit. $\left.{ }^{4{ }^{3}} J_{\mathrm{HF}}=21.0\right]$; syn $12{ }^{3} J_{\mathrm{HF}}=23$ [lit. $\left.{ }^{4 \mathrm{c}}{ }^{3} J_{\mathrm{HF}}=23.8\right]$ ). The poor level of diastereocontrol for the fluorodesilylation of compound 7 was expected as the absence of silylated stereogenic centre induced the presence of reactive conformations too close in energy. 


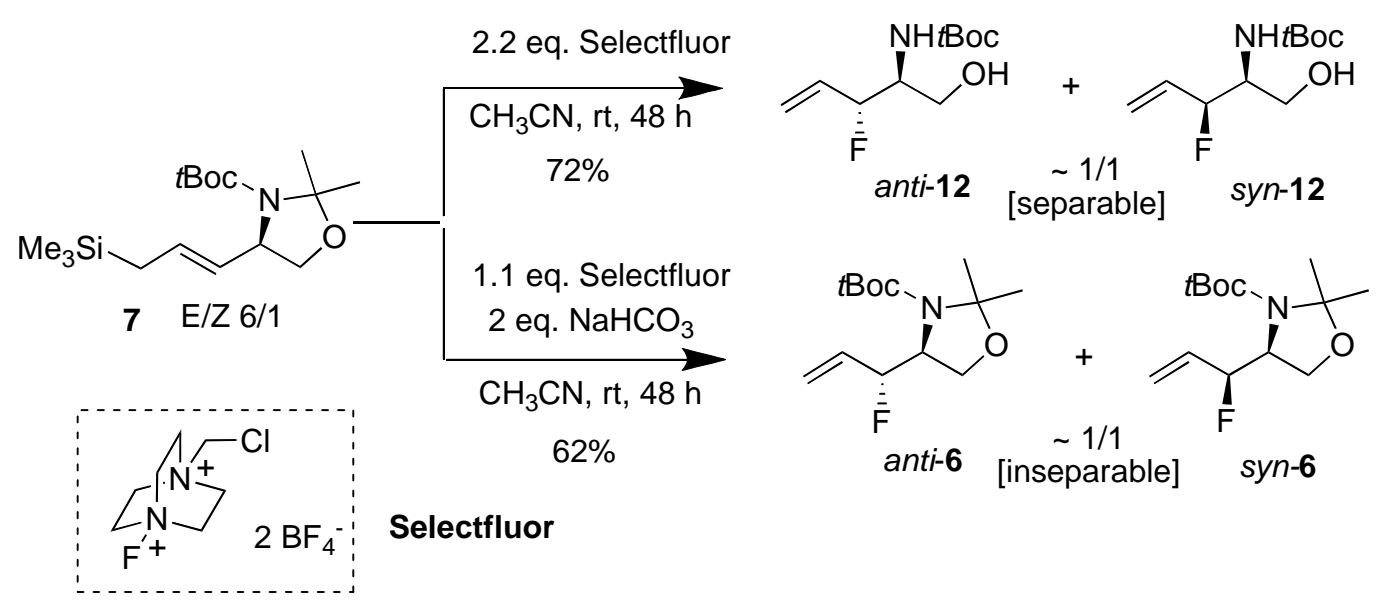

Scheme 5. Electrophilic fluorination of allylsilane 7.

The last stage of the proposed synthetic scheme was the introduction of the long alkyl chain by cross-metathesis. In a previous study, we showed that the cross-metathesis of allylic fluorides required drastic conditions to take place in synthetically useful yields. ${ }^{6}$ For optimization studies, we used the mixture of diastereomers syn-6 and anti-6 keeping the valuable pure diastereomers syn-12 and anti-12 to complete the formal synthesis of $\mathbf{5}$ (Scheme 6). After detailed investigation, we found that the second generation Grubbs' catalyst $\mathbf{1 0}$ was not a suitable catalyst for the cross-coupling of allylsilane 7 with 1-pentadecene. Indeed, analysis of the reaction mixture by mass spectrometry revealed the presence of multiple products varying in their molecular weights by a factor of 14 suggesting double bond isomerization followed by cascade addition and deletion of methylene groups under these reaction conditions. Double bond isomerization mediated by ruthenium-based catalysts is not unprecedented and has been observed by other groups. ${ }^{19}$ To overcome this difficulty, the crosscoupling was subsequently carried out in dichloromethane at $70^{\circ} \mathrm{C}$ in a pressure tube in the presence of $10 \mathrm{~mol} \%$ of the Hoveyda-Grubbs catalyst 11. Under these conditions, mass spectrometry of the crude revealed the presence of a single product with a molecular mass of 441.7. Further analyses certified the identity of the cross-coupled product as being syn and anti13. After purification by silica gel chromatography, this compound was isolated in $45 \%$ yield as an inseparable mixture of syn and anti stereoisomers. Careful analysis of fractions enriched in one or the other stereoisomer allowed us to assign the E-stereochemistry for the newly formed disubstituted alkene.

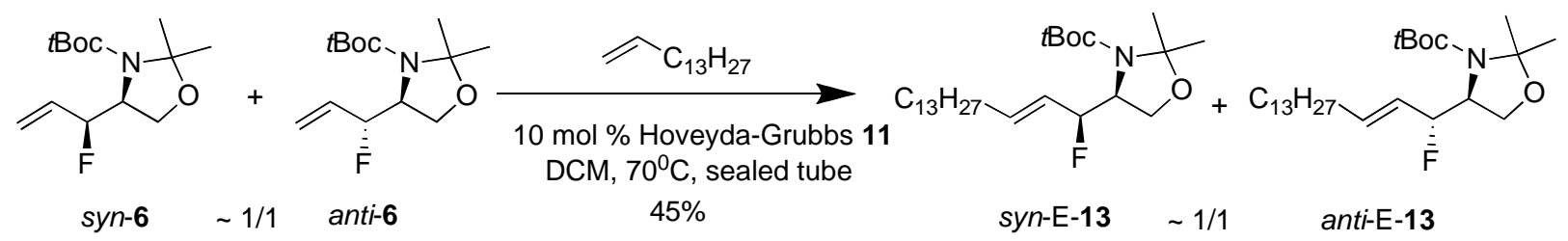

Scheme 6. Cross-metathesis of 6. 
The pure diastereomers syn-12 and anti-12 were then subjected to these optimized reaction conditions. A small scale cross-metathesis of syn-12 gave the desired compound syn-14 in a $35 \%$ yield. However, mass spectrometry analysis revealed the presence of a series of several fluorinated products with various alkyl chain length, a result similar to the product distribution observed for the metathesis reaction of syn-6 and anti-6 using the second generation Grubbs' catalyst $10{ }^{20}$ Gratifyingly, the metathesis of anti-12 with 1-pentadecene using $10 \mathrm{~mol} \%$ of the Hoveyda-Grubbs catalyst 11 gave the desired compound anti-14 in a 58\% yield with excellent level of stereocontrol $(E / Z>99: 1)$. Careful mass spectrometry analysis of this compound confirmed unambiguously the presence of a single product. These results revealed that, although clean metathesis cross-coupling is possible on these substrates, the reaction can suffer from reproducibility, especially when carried out on small scale. ${ }^{21}$ The clean cross-coupling of anti-12 with 1-pentadecene completes the formal synthesis of the fluorinated analogue of sphingosine 5 (Scheme 7).
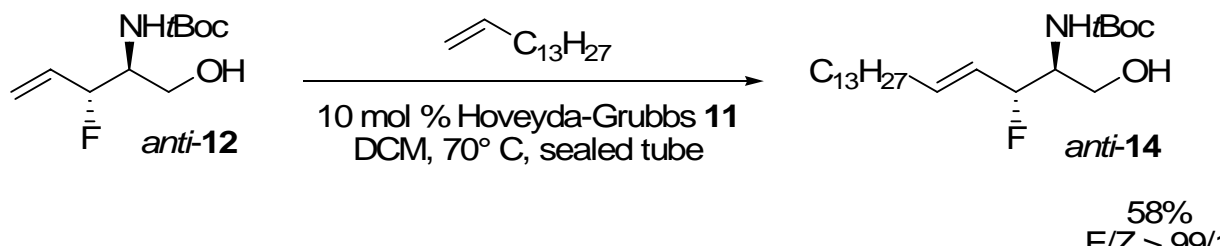

Scheme 7. Cross metathesis anti-12.

\section{Conclusions}

In conclusion, we have developed a novel route to fluorinated analogues of sphingosine based on two cross-metathesis couplings and a fluorodesilylation process, anti-14 was synthesized in an overall yield of $21 \%$ in 4 steps from Garner's aldehyde. This is the first route to these targets relying on the use of an electrophilic fluorinating reagent. We discovered that the key fluorodesilylation is coupled with a clean deprotection releasing the primary alcohol but leaving the N-Boc group intact, when the reaction is carried out with Selectfluor in acetonitrile. Notably, this deprotection can be totally avoided by adding $\mathrm{NaHCO}_{3}$ as a co-reagent. The product outcome for the electrophilic fluorination step has been vastly improved in comparison with known strategy based on DAST-mediated nucleophilic fluorination as it did not suffer from double bond transposition or the formation of non-fluorinated compounds. However, the level of diastereocontrol observed upon fluorodesilylation requires optimization. We also successfully attached the long alkyl chain to the terminal allylic fluoride via a highly stereoselective olefin cross metathesis reaction. For this transformation, it was found that under the reaction conditions applied for the cross-metathesis, double bond isomerization and subsequent uncontrolled cross-metathesis could lead to a mixture of products. With a robust and 
convergent synthesis of a fluorinated sphingosine in place, we are currently actively working on improving the level of distereocontrol for the fluorination step, thereby facilitating rapid access to various fluorinated analogues.

\section{Acknowledgements}

The BBSRC (Industrial Studentship BBS/S/M/2005/12407 to HT), the EPSRC (GR/S43283/01 to MT) and the European Community (MRTN-CT-2003-501721 to ST) are gratefully acknowledged for generous financial support. We also thank the analytical staff of the CRL for support with analysis of samples.

\section{Experimental Section}

tert-Butyl-(4R)-2,2-dimethyl-4-vinyl-1,3-oxazolidine-3-carboxylate (9). Methyltriphenylphosphonium bromide ( $2.2 \mathrm{~g}$, 2 eq.) was suspended in anhydrous THF $(60 \mathrm{~mL})$ under $\mathrm{N}_{2}$ and KHMDS ( $0.5 \mathrm{M}$ in toluene, $12 \mathrm{~mL}, 2$ eq.) was added. The resulting yellow suspension was stirred at $\mathrm{rt}$ for $60 \mathrm{~min}$ then cooled to $-78^{\circ} \mathrm{C}$ and a solution of aldehyde $8(700 \mathrm{mg}, 3.06 \mathrm{mmol})$ in THF $(8 \mathrm{~mL})$ was added dropwise. The cooling bath was removed and the mixture stirred at rt for 16 hours. The reaction was quenched with $\mathrm{MeOH}(5 \mathrm{~mL})$ and the resulting mixture poured into a solution of sat. potassium sodium tartrate and $\mathrm{H}_{2} \mathrm{O}(1: 1,120 \mathrm{~mL})$. The mixture was then concentrated under reduced pressure to remove $\mathrm{MeOH}$ and THF. Extraction with ether $(2 \times 60 \mathrm{~mL})$, drying $\left(\mathrm{MgSO}_{4}\right)$ and evaporation of the solvent under reduced pressure furnished a colourless oil. Purification by column chromatography (diethyl ether: hexane, 1:4) afforded 9 as a colourless liquid (630 $\mathrm{mg}, 90 \%$ ), the spectroscopic data for which were fully consistent with those reported; ${ }^{11}[\alpha]_{\mathrm{D}}=+14.5^{\circ}\left(\mathrm{c}=1.0 \mathrm{CHCl}_{3}\right)\left(\right.$ lit. $\left.^{11}+15.6^{\circ}\right)$.

tert-Butyl-(4R)-2,2-dimethyl-4-(3-trimethylsilanyl-propenyl)-1,3-oxazolidine-3-carboxylate (7). To a solution of olefin $9(0.227 \mathrm{~g}, 1 \mathrm{mmol})$ in $\mathrm{CH}_{2} \mathrm{Cl}_{2}(3 \mathrm{~mL})$ was added titanium isopropoxide $(0.09 \mathrm{~mL}, 30 \mathrm{~mol} \%)$, the reaction mixture was then refluxed at $45^{\circ} \mathrm{C}$ under an atmosphere of argon. After 1 hour, the reaction was cooled to room temperature and allyltrimethylsilane $(0.47 \mathrm{~mL}, 3 \mathrm{mmol})$ was added. The reaction was then heated to reflux ( $45^{\circ}$ C), and Grubbs second generation catalyst $(0.085 \mathrm{~g}, 10 \mathrm{~mol} \%)$ was then added as a solid (in four portions over 48 hours); the reaction was left to reflux for 48 hours and was monitored by t.l.c. The mixture was then concentrated under reduced pressure. Purification by flash chromatography (diethyl ether: hexane, 1:4) afforded compound 7 (0.202 g, 65\%). E:Z $=6: 1$ after purification. $[\alpha]_{\mathrm{D}}=-27.7^{\circ}\left(\mathrm{c}=1.0, \mathrm{CHCl}_{3}\right) ;{ }^{1} \mathrm{H} \mathrm{NMR}\left(\mathrm{CDCl}_{3}, 400 \mathrm{MHz}\right), \delta 5.63(\mathrm{~m}, 1 \mathrm{H}$, $\left.\mathrm{CH}=\mathrm{CHCH}_{2}\right), 5.28\left(\mathrm{~m}, 1 \mathrm{H}, \mathrm{CH}=\mathrm{CHCH}_{2}\right), 4.28\left(\mathrm{~m}, 1 \mathrm{H}, \mathrm{OCH}_{2} \mathrm{CHNBoc}\right), 4.01$ (dd, J=8.7, 6.0 $\mathrm{Hz}, 1 \mathrm{H}, \mathrm{O} \mathrm{CH} \mathrm{CHNBoc}_{2}, 3.70$ (dd, J=8.6, $1.9 \mathrm{~Hz}, 1 \mathrm{H}, \mathrm{O} \mathrm{CH}_{2} \mathrm{CHNBoc}$ ), 1.49 (m, 17H, $\mathrm{OC}\left(\mathrm{CH}_{3}\right)_{2} \mathrm{~N}, \mathrm{OC}\left(\mathrm{CH}_{3}\right)_{3}$ and $\left.\mathrm{CH}=\mathrm{CHCH}_{2} \mathrm{TMS}\right), 0.07$ and $0.01\left(2 \mathrm{~s}, 9 \mathrm{H}, \mathrm{Si}\left(\mathrm{CH}_{3}\right)_{3}\right) ;{ }^{13} \mathrm{C}-\mathrm{NMR}$ 
$\left(\mathrm{CDCl}_{3}, 100.6 \mathrm{MHz}\right) \delta 152.0$ (-NCOO-), 131.0, 129.5, 128.0, $124.3\left(4 \mathrm{CH}, \mathrm{CH}=\mathrm{CHCH}_{2}\right.$ cis and


$\left.\mathrm{OCH}_{2} \mathrm{CHNBoc}\right), 28.6\left(\mathrm{CH}_{3}, \mathrm{OC}\left(\mathrm{CH}_{3}\right)_{3}\right), 26.5$ and $23.8\left(\mathrm{CH}_{3},-\mathrm{OC}\left(\mathrm{CH}_{3}\right)_{2} \mathrm{~N}-\right), 22.6\left(\mathrm{CH}_{2}\right.$, $\left.\mathrm{CH}=\mathrm{CHCH}_{2}\right),-1.3$ and $-2.0\left(\mathrm{CH}_{3}, \mathrm{Si}\left(\mathrm{CH}_{3}\right)_{3}\right) ;(\mathrm{FI})^{+} \mathrm{m} / \mathrm{z}$ : HRMS required for $\mathrm{C}_{16} \mathrm{H}_{31} \mathrm{NO}_{3} \mathrm{Si}$ $\left(\left[\mathrm{M}^{+}\right]\right)$313.2073 found 313.2079; IR (film) $v_{\max }\left(\mathrm{cm}^{-1}\right)$ 1700, 1385.

tert-Butyl-(4S)-4-(1-fluoroprop-2-en-1-yl)-2,2-dimethyl-1,3-oxazolidine-3-carboxylate (6). To a solution of allylsilane $7(0.196 \mathrm{~g}, 0.63 \mathrm{mmol})$ in acetonitrile $(6 \mathrm{~mL})$, was added Selectfluor ${ }^{\mathrm{TM}}$ (0.33 g, 1.5 eq.) and $\mathrm{NaHCO}_{3}(0.105 \mathrm{~g}, 2$ eq. $)$. The reaction mixture was stirred at $r$ under an atmosphere of nitrogen for 20 hours before concentrating under reduced pressure. Purification by flash chromatography (diethyl ether: hexane, 1:19) afforded compound 6 as an inseparable mixture of diastereoisomers $(0.116 \mathrm{~g}, 72 \%$ ). de $=6 \%$ (as calculated from the crude ${ }^{19} \mathrm{~F}$ NMR). ${ }^{1} \mathrm{H}$ NMR $\left(\mathrm{CDCl}_{3}, 400 \mathrm{MHz}\right), \delta 5.84\left(\mathrm{~m}, 1 \mathrm{H}, \mathrm{CH}=\mathrm{CH}_{2}\right), 5.33\left(\mathrm{~m}, 2 \mathrm{H}, \mathrm{CH}=\mathrm{CH}_{2}\right)$, $5.05\left(\mathrm{dm}, J^{\mathrm{HF}}=48.1 \mathrm{~Hz}, 1 \mathrm{H}, \mathrm{CHF}\right), 4.00\left(\mathrm{~m}, 3 \mathrm{H},-\mathrm{OCH}_{2} \mathrm{CH}(\mathrm{CF}) \mathrm{N}-\right), 1.48\left(\mathrm{~m}, 15 \mathrm{H}, \mathrm{OC}\left(\mathrm{CH}_{3}\right)_{3}\right.$ and $\left.-\mathrm{OC}\left(\mathrm{CH}_{3}\right)_{2} \mathrm{~N}-\right) ;{ }^{13} \mathrm{C}-\mathrm{NMR}\left(\mathrm{CDCl}_{3}, 100.6 \mathrm{MHz}\right) \delta 152.4(-\mathrm{NCOO}-), 133.6\left(\mathrm{CH}, \mathrm{CH}=\mathrm{CH}_{2}\right)$,

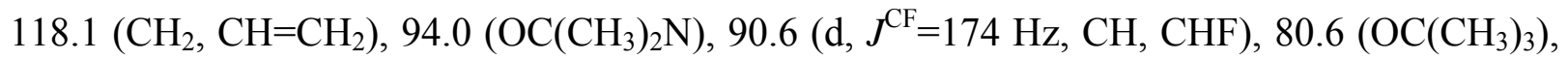
$62.9\left(\mathrm{CH}_{2},-\mathrm{OCH}_{2} \mathrm{CH}(\mathrm{CF}) \mathrm{N}-\right), 59.7\left(\mathrm{CH},-\mathrm{OCH}_{2} \mathrm{CH}(\mathrm{CF}) \mathrm{N}-\right), 28.4\left(\mathrm{CH}_{3}, \mathrm{OC}\left(\mathrm{CH}_{3}\right)_{3}\right), 26.8$ and $24.6\left(\mathrm{CH}_{3},-\mathrm{OC}\left(\mathrm{CH}_{3}\right)_{2} \mathrm{~N}-\right) ;{ }^{19} \mathrm{~F}\left\{{ }^{1} \mathrm{H}\right\}-\mathrm{NMR}\left(\mathrm{CDCl}_{3}, 400 \mathrm{MHz}\right) \delta-190.4,-194.7 ; \mathrm{m} / \mathrm{z}: \mathrm{HRMS}$ required for $\mathrm{C}_{13} \mathrm{H}_{22} \mathrm{FNNaO}_{3}$, calculated mass is 282.1476 and found $282.1473\left([\mathrm{M}+\mathrm{Na}]^{+}\right)$; IR (film) $v_{\max }\left(\mathrm{cm}^{-1}\right) 1703,1387,1174$.

(2-Fluoro-1-hydroxymethyl-but-3-enyl)-carbamic acid tert-butyl ester (12). A solution of 7 (173 mg, $0.55 \mathrm{mmol}, 0.6 \mathrm{M}$ ) in acetonitrile and Selectfluor ${ }^{\mathrm{TM}}$ (196 mg, 1 eq.) was stirred at $\mathrm{rt}$ under nitrogen for 2 days. When the reaction was complete, the mixture was concentrated under reduced pressure. Purification by column chromatography (diethyl ether: hexane, 2:3) afforded $50 \mathrm{mg}$ of the erythro diastereoisomer, and $25 \mathrm{mg}$ of the threo diastereoisomer (62\%, erythro:threo, $1: 1)$.

((1S, 2R)-2-Fluoro-1-hydroxymethyl-but-3-enyl)-carbamic acid tert-butyl ester (anti-12). $[\alpha]_{\mathrm{D}}=-6^{\circ}\left(\mathrm{c}=0.5, \mathrm{CHCl}_{3}\right) ;{ }^{1} \mathrm{H} \mathrm{NMR}\left(\mathrm{CDCl}_{3}, 400 \mathrm{MHz}\right) \delta 5.94\left(\mathrm{~m}, 1 \mathrm{H}, \mathrm{CH}=\mathrm{CH}_{2}\right), 5.45(\mathrm{dm}, 1 \mathrm{H}$, $\left.J=17.3 \mathrm{~Hz}, \mathrm{C}=\mathrm{CH}_{2}\right), 5.36\left(\mathrm{dm}, 1 \mathrm{H}, J=10.7 \mathrm{~Hz}, \mathrm{C}=\mathrm{CH}_{2}\right), 5.07\left(\mathrm{dm}, J^{\mathrm{HF}}=47.4 \mathrm{~Hz}, 2 \mathrm{H}, \mathrm{NH}\right.$

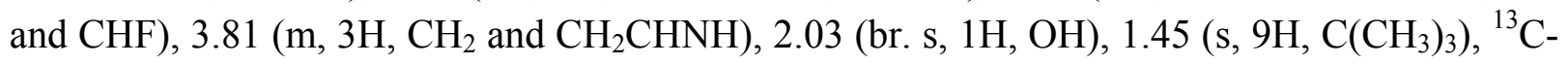
NMR $\left(\mathrm{CDCl}_{3}, 100.6 \mathrm{MHz}\right) \delta 153.2(\mathrm{C}=\mathrm{O}), 133.2\left(\mathrm{CH}=\mathrm{CH}_{2}\right), 119.2\left(\mathrm{CH}=\mathrm{CH}_{2}\right), 92.4\left(\mathrm{~d}, J^{\mathrm{CF}}=\right.$

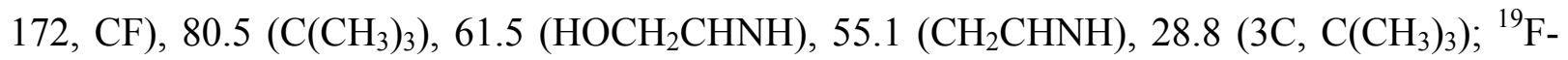
NMR $\left(\mathrm{CDCl}_{3}, 400 \mathrm{MHz}\right) \delta-190.98\left({ }^{3} \mathrm{~J}_{\mathrm{HF}}=20 \mathrm{~Hz}\right)$. IR (film) $v_{\max }\left(\mathrm{cm}^{-1}\right) 3441,2982,1706$, 1504, 1265; ((1S, 2S)-2-Fluoro-1-hydroxymethyl-but-3-enyl)-carbamic acid tert-butyl ester (syn-12). $[\alpha]_{\mathrm{D}}=-11.7^{\circ}\left(\mathrm{c}=0.9, \mathrm{CHCl}_{3}\right) ;{ }^{1} \mathrm{H} \mathrm{NMR}\left(\mathrm{CDCl}_{3}, 400 \mathrm{MHz}\right) \delta 5.93\left(\mathrm{~m}, 1 \mathrm{H}, \mathrm{CH}=\mathrm{CH}_{2}\right)$, $5.54\left(\mathrm{dm}, 1 \mathrm{H}, J=17.3 \mathrm{~Hz}, \mathrm{CH}=\mathrm{CH}_{2}\right), 5.36\left(\mathrm{dm}, 1 \mathrm{H}, J=10.8 \mathrm{~Hz}, \mathrm{CH}=\mathrm{CH}_{2}\right), 5.16\left(\mathrm{dm}, J^{\mathrm{HF}}=\right.$

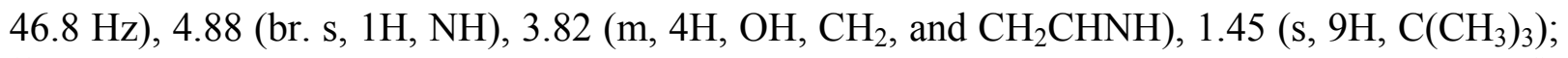
${ }^{13} \mathrm{C}-\mathrm{NMR}\left(\mathrm{CDCl}_{3}, 100.6 \mathrm{MHz}\right) \delta 156.2(\mathrm{C}=\mathrm{O}), 133.1\left(\mathrm{CH}=\mathrm{CH}_{2}\right), 118.8\left(\mathrm{CH}=\mathrm{CH}_{2}\right), 92.3\left(\mathrm{~d}, J^{\mathrm{CF}}\right.$

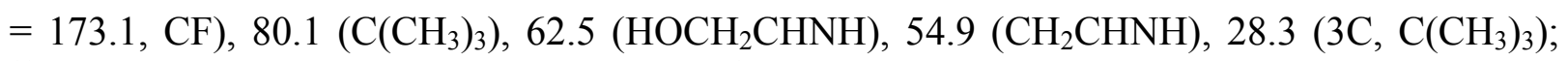
${ }^{19} \mathrm{~F}-\mathrm{NMR}\left(\mathrm{CDCl}_{3}, 400 \mathrm{MHz}\right) \delta-195.48\left({ }^{3} \mathrm{~J}_{\mathrm{HF}}=23\right)$; HRMS $\left(\mathrm{GCT}, \mathrm{CI}^{+}\right)$: calculated for $\mathrm{C}_{10} \mathrm{H}_{19} \mathrm{FNO}_{3} 220.1349$, found 220.1354; IR (film) $v_{\max }\left(\mathrm{cm}^{-1}\right)$ 1706, 1504, 1265. 


\section{tert-Butyl-(4S)-4-(1-fluorohexadec-2-enyl)-2,2-dimethyl-1,3-oxazolidine-3-carboxylate}

(13). tert-Butyl-(4S)-4-(1-fluoroprop-2-en-1-yl)-2,2-dimethyl-1,3-oxazolidine-3-carboxylate $(0.050 \mathrm{~g}, 0.19 \mathrm{mmol})$ and 1-pentadecene $(0.27 \mathrm{~mL}, 5 \mathrm{eq})$ were solubilised in anhydrous $\mathrm{CH}_{2} \mathrm{Cl}_{2}$ $(1.2 \mathrm{~mL})$ under an atmosphere of nitrogen. Hoveyda-Grubbs $2^{\text {nd }}$ Generation catalyst $(0.006 \mathrm{~g}$, $5 \mathrm{~mol} \%$ ) was added as a solid, and the reaction mixture was allowed to stir, in a sealed tube for 12 hours at $70^{\circ} \mathrm{C}$. The reaction mixture was then cooled to room temperature and concentrated under reduced pressure. Purification by flash chromatography (diethyl ether: hexane, 1:19) afforded the compound 13 as an inseparable mixture of diastereoisomers $(0.038 \mathrm{~g}, 46 \%) .{ }^{1} \mathrm{H}$ NMR $\left(\mathrm{CDCl}_{3}, 400 \mathrm{MHz}\right) \delta 5.81\left(\mathrm{~m}, 1 \mathrm{H}, \mathrm{CH}=\mathrm{CHC}_{13} \mathrm{H}_{27}\right), 5.51\left(\mathrm{~m}, 1 \mathrm{H}, \mathrm{CH}=\mathrm{CHC}_{13} \mathrm{H}_{27}\right), 5.10$

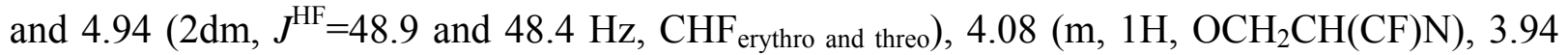
$\left(\mathrm{m}, 2 \mathrm{H}, \mathrm{OCH}_{2} \mathrm{C}(\mathrm{CF}) \mathrm{N}\right), 2.04\left(\mathrm{~m}, 2 \mathrm{H}, \mathrm{CH}=\mathrm{CHCH}_{2} \mathrm{C}_{12} \mathrm{H}_{25}\right), 1.48\left(\mathrm{~m}, 15 \mathrm{H}, \mathrm{OC}_{2} \mathrm{CH}_{3}\right)_{3}$ and $\mathrm{OC}\left(\mathrm{CH}_{3}\right)_{2} \mathrm{~N}-$ ), 1.25 (br s, $\left.22 \mathrm{H},\left(\mathrm{CH}_{2}\right)_{11}\right), 0.88$ (t, $\left.J=7.0,3 \mathrm{H}, \mathrm{CH}=\mathrm{CHC}_{12} \mathrm{H}_{24} \mathrm{CH}_{3}\right) ;{ }^{13} \mathrm{C}-\mathrm{NMR}$ $\left(\mathrm{CDCl}_{3}, 100.6 \mathrm{MHz}\right) \delta 152.4(\mathrm{C}=\mathrm{O}), 136.8\left(\mathrm{CH}, \mathrm{CH}=\mathrm{CHC}_{13} \mathrm{H}_{27}\right), 125.2\left(\mathrm{CH}, \mathrm{CH}=\mathrm{CHC}_{13} \mathrm{H}_{27}\right)$,

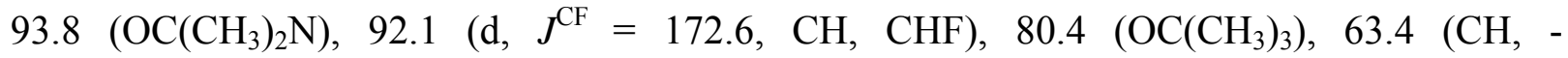
$\left.\mathrm{OCH}_{2} \mathrm{CH}(\mathrm{CF}) \mathrm{N}-\right), 60.4\left(\mathrm{CH}_{2}, \mathrm{OCH}_{2} \mathrm{CH}(\mathrm{CF}) \mathrm{N}\right), 31.6,31.9,29.7,22.7,21.0\left(\mathrm{CH}_{2},\left(\mathrm{CH}_{2}\right)_{12}\right)$, $28.4\left(\mathrm{CH}_{3}, \mathrm{OC}\left(\mathrm{CH}_{3}\right)_{3}\right), 26.9$ and $\left.24.7\left(\mathrm{CH}_{3},-\mathrm{OC}\left(\mathrm{CH}_{3}\right)_{2} \mathrm{~N}-\right), 14.1\left(\mathrm{CH}_{3},\left(\mathrm{CH}_{2}\right)_{12} \mathrm{CH}_{3}\right)\right)$; ${ }^{19} \mathrm{~F}-\mathrm{NMR}$ $\left(\mathrm{CDCl}_{3}, 400 \mathrm{MHz}\right) \delta-183.0,-186.0 ; \mathrm{m} / \mathrm{z}$ : HRMS required for $\mathrm{C}_{26} \mathrm{H}_{48} \mathrm{FNO}_{3}$ mass is 441.3600 , found 441.3618; IR (film) $v_{\max }\left(\mathrm{cm}^{-1}\right)$ 2926, 1704, 1386.

tert-Butyl (2S,E)-3-fluoro-1-hydroxyoctadec-4-en-2-ylcarbamate (14). General procedure for the cross metathesis reaction of allylic fluoride 12, with 1-pentadecene. To a solution of a pure diastereoisomer of allylic fluoride 12 in $\mathrm{CH}_{2} \mathrm{Cl}_{2}$, was added 1-pentadecene (5 eq.) and Hoveyda-Grubbs' second generation catalyst (10 mol\%). The reaction mixture was stirred at $70^{\circ} \mathrm{C}$ in a sealed tube for 16 hours. After cooling to room temperature, the reaction mixture was concentrated under reduced pressure. Purification by column chromatography yielded the desired compound $\mathbf{1 4}$ as a single diastereomer.

tert-butyl (2S,3R,E)-3-fluoro-1-hydroxyoctadec-4-en-2-ylcarbamate (anti-14). Following the general procedure, anti-12 $(40 \mathrm{mg}, 0.182 \mathrm{mmol})$ was reacted with 1-pentadecene $(0.25 \mathrm{~mL}$, 5 eq.) in $1 \mathrm{~mL}$ of $\mathrm{CH}_{2} \mathrm{Cl}_{2}$. Column chromatography afforded anti-14 (42 mg) in 58\% yield. $[\alpha]_{\mathrm{D}}=-26.1^{\circ}\left(\mathrm{c}=1.0, \mathrm{CHCl}_{3}\right) ;{ }^{1} \mathrm{H} \mathrm{NMR}\left(\mathrm{CDCl}_{3}, 400 \mathrm{Mhz}\right) \delta 5.87\left(\mathrm{~m}, 1 \mathrm{H}, \mathrm{CH}=\mathrm{CHC}_{13} \mathrm{H}_{27}\right), 5.57$ $\left(\mathrm{m}, 1 \mathrm{H}, \mathrm{CH}=\mathrm{CHC}_{13} \mathrm{H}_{27}\right), 5.02\left(\mathrm{dm}, J^{\mathrm{HF}}=48.3 \mathrm{~Hz}, 2 \mathrm{H}, \mathrm{CHF}\right.$ and $\left.\mathrm{NH}\right), 3.82(\mathrm{~m}, 3 \mathrm{H}$, $\left.\mathrm{HOCH}_{2} \mathrm{CH}(\mathrm{CF}) \mathrm{N}\right), 2.20$ (br s, $\left.1 \mathrm{H}, \mathrm{OH}\right), 2.07$ (m, 2H, $\left.\mathrm{CH}=\mathrm{CHCH}_{2} \mathrm{C}_{12} \mathrm{H}_{27}\right), 1.45$ (s, 9H, $\left.\mathrm{C}\left(\mathrm{CH}_{3}\right)_{3}\right), 1.26\left(\mathrm{~s}, 22 \mathrm{H}, \mathrm{CH}_{2} \mathrm{C}_{11} \mathrm{H}_{22} \mathrm{CH}_{3}\right), 0.88\left(\mathrm{~m}, 3 \mathrm{H}, \mathrm{C}_{12} \mathrm{H}_{24} \mathrm{CH}_{3}\right) ;{ }^{13} \mathrm{C}-\mathrm{NMR}\left(\mathrm{CDCl}_{3}, 100.6\right.$ $\mathrm{MHz}) \delta 155.9(\mathrm{C}=\mathrm{O}), 137.8\left(\mathrm{CH}=\mathrm{CHC}_{13} \mathrm{H}_{27}\right), 124.5\left(\mathrm{CH}=\mathrm{CHC}_{13} \mathrm{H}_{27}\right), 93.6\left(\mathrm{~d}, J^{\mathrm{CF}}=170.7\right.$, $\mathrm{CHF}), \quad 79.9 \quad\left(\mathrm{OC}_{\left.\left(\mathrm{CH}_{3}\right)_{3}\right),} 65.9 \quad\left(\mathrm{CH}_{2}, \quad \mathrm{HOCH}_{2}\right), \quad 61.4 \quad\left(\mathrm{HOCH}_{2} \mathrm{CH}(\mathrm{CF}) \mathrm{N}\right), \quad 31.9\right.$ $\left(\mathrm{CH}=\mathrm{CHCH}_{2} \mathrm{C}_{12} \mathrm{H}_{25}\right), \quad 29.8, \quad 29.7, \quad 29.6, \quad 29.5, \quad 29.4, \quad 29.2$ and $28.8 \quad\left(\mathrm{CH}_{2}\right.$, $\left.\mathrm{CH}=\mathrm{CHCH}_{2}\left(\mathrm{CH}_{2}\right)_{10} \mathrm{CH}_{2} \mathrm{CH}_{3}\right), 28.3\left(\mathrm{CH}_{3}, \mathrm{C}\left(\mathrm{CH}_{3}\right)_{3}\right), 22.7\left(\mathrm{CH}_{2}, \mathrm{CH}=\mathrm{CHCH}_{2}\left(\mathrm{CH}_{2}\right)_{10} \mathrm{CH}_{2} \mathrm{CH}_{3}\right)$, $14.1\left(\mathrm{CH}_{3}, \mathrm{CH}=\mathrm{CHCH}_{2}\left(\mathrm{CH}_{2}\right){ }_{10} \mathrm{CH}_{2} \mathrm{CH}_{3}\right) ;{ }^{19} \mathrm{~F}\left\{{ }^{1} \mathrm{H}\right\}-\mathrm{NMR}\left(\mathrm{CDCl}_{3}, 400 \mathrm{MHz}\right) \delta-182.8 ; \mathrm{HRMS}$ required for $\mathrm{C}_{23} \mathrm{H}_{44} \mathrm{FNNaO}_{3}$ mass is 424.3198 , found 424.3197; IR (film) $v_{\max }\left(\mathrm{cm}^{-1}\right) 3020$, 2928, 1709, 1504, 1265. 
tert-Butyl (2S,3S,E)-3-fluoro-1-hydroxyoctadec-4-en-2-ylcarbamate (syn-14). Following the general procedure, syn-12 (11 mg, $0.068 \mathrm{mmol})$ was reacted with 1-pentadecene $(0.068 \mathrm{~mL}, 5$ eq.) in $0.5 \mathrm{~mL}$ of $\mathrm{CH}_{2} \mathrm{Cl}_{2}$. Column chromatography afforded syn-14 (7 mg) in $35 \%$ yield, however analysis by mass spectrometry indicated a mixture of several different products of varying alkyl chain length, corresponding to similar double bond isomerisation as shown with Grubbs second generation catalyst on the protected allylic fluoride.

\section{References and Notes}

1. (a) Stahelin, R. V.; Hwang, J. H.; Kim, J-H.; Park, Z.-Y.; Johnson, K. R.; Obeid, L. M. J. Biol. Chem. 2005, 280, 43030. (b) Spiegel, S.; Milstein, S. Nat. Rev. Mol. Cell Biol. 2003, 5, 397. (c) Cremesti, A. E.; Goni, F. M.; Kolenesnick, R. FEBS Lett. 2002, 531, 47. (d) Smith, W. L.; Merrill, Jr, A. H. J. Biol. Chem. 2002, 277, 25841. (e) Simons, K.; Ikonen, E. Science 2000, 290, 1721. (f) Kolter, T.; Sandhoff, K. Angew. Chem. Int. Ed. 1999, 38, 1532. (g) Simons, K.; Ikonen, E. Nature 1997, 387, 569. (h) Hannun, Y. A. Science 1996, 274, 1855. (i) Yatomi, Y.; Ruan, F.; Hakomori, S.; Igarashi, Y. Blood. 1995, 86, 193.

2. (a) Kimura, T.; Boehmler, A. M.; Seitz, G.; Kuci, S.; Wiesner, T.; Brinkmann, V.; Kanz. L.; Mőhle, R. Blood. 2004, 103, 4478. (b) Xie, J. H.; Nomura, N.; Koprak, S. L.; Quackenbush, E. J.; Forrest, M. J.; Rosen, H. J. Immunol. 2003, 170, 3662. (c) Mandala, S.; Hajdu, R.; Bergstrom, J.; Quackenbush, E.; Xie, J.; Milligan, J.; Thornton, R.; Shei, GJ.; Card, D.; Keohane, C.; Rosenbach, M.; Hale, J.; Lynch, C. L.; Rupprecht, K.; Parsons, W.; Rosen, H. Science. 2002, 296, 346. (d) Payne, S. G.; Milstien, S.; Spiegel, S. FEBS Lett. 2002, 531, 54. (e) Lee, M-J.; Thangada, S.; Claffey, K. P.; Ancellin, N.; Liu, C. H.; Kluk, M.; Volpi, M.; Sha'afi, R. I.; Hla, T. Cell. 1999, 99, 310. (f) Meyer zu Heringdorf, D.; van Koppen, C. J.; Jakobs, K. H. FEBS Lett. 1997, 410, 34.

3. (a) Tarnowski, A.; Retz, O.; Baer, T.; Schmidt, R. R. Eur. J. Org. Chem. 2005, 6, 1129. (b) Van den Berg, R. J. B. H. N.; Korevaar, C. G. N.; Overkleeft, H. S.; Van der Marel, G.; Van Boom, J. H. J. Org. Chem. 2004, 69, 5699. (c) Lu, X.; Cseh, S.; Byun, H-S.; Tigyi, G.; Bittman, R. J. Org. Chem. 2003, 68, 7046. (d) Murakami, T.; Furusawa, K. Tetrahedron. 2002, 58, 9257. (e) Corey, E. J.; Choi, S. Tetrahedron Lett. 2000, 41, 2765. (f) He, L.; Byun, H-S.; Bittman, R. J. Org. Chem. 2000, 65, 7627.

4. (a) Van Overmeire, I.; Boldin, S. A.; Venkataraman, K.; Zisling, R.; De Jonghe, S.; Van Calenbergh, S.; De Keukeleire, D.; Futerman, A. H.; Herdewijn, P. J. Med. Chem. 2000, 43, 4189. (b) De Jonghe, S.; Van Overmeire, I.; Gunst, J.; De Bruyn, A.; Hendrix, C.; Van Calenbergh, S.; Busson, R.; De Keukeleire, D.; Philippé, J.; Herdewijn, P. Bioorg. Med. Chem. Lett. 1999, 9, 3159. (c) Khiar, N.; Singh, K.; Garcia, M.; Martin-Lomas, M. Tetrahedron Lett. 1999, 40, 5779-5782. (d) Kozikowski, A. P.; Wu, J.-P. Tetrahedron Lett. 1990, 31, 4309. (e) Herold, P. Helv. Chim. Acta 1988, 71, 354.

5. (a) Yamamoto, T.; Hasegawa, H.; Hakogi, T.; Katsumura, S. Org. Lett. 2006, 8, 5569. (b) 
Nussbaumer, P.; Ettmayer, P.; Carsten, P.; Rosenbeiger, D.; Högenauer. K. Chem. Commun. 2005, 40, 5086. (c) Rai, A. N.; Basu, A. Org. Lett. 2004, 6, 2861. (d) Torssell, S.; Somfai, P. Org. Biomol. Chem. 2004, 2, 1643.

6. Thibaudeau, S.; Fuller, R.; Gouverneur, V. Org. Biomol. Chem. 2004, 2, 1110.

7. (a) Tredwell, M.; Gouverneur, V. Org. Biomol, Chem. 2006, 4, 26. (b) Giuffredi, G.; Bobbio, C.; Gouverneur, V. J. Org. Chem. 2006, 71, 5361. (c) Tredwell, M.; Tenza, K.; Pacheco, M.; Gouverneur, V. Org. Lett. 2005, 7, 4495. (d) Thibaudeau, S.; Gouverneur, V. Org. Lett. 2003, 5, 4891. (e) Greedy, B.; Paris, J.-M.; Vidal, T.; Gouverneur, V. Angew. Chem. Int. Ed. 2003, 42, 3291.

8. (a) Liang, X.; Andersch, J.; Bols, M. J. Chem. Soc., Perkins Trans. 1, 2001, 2136. (b) Garner, P.; Park, J. M. J. Org. Chem. 1987, 52, 2361.

9. Seyferth, D.; Wursthorn, K.; Lim, T. F.; Sepelak, D. J.; J. Organomet. Chem. 1979, 293.

10. Fleming, I.; Paterson, I. Synthesis. 1979, 446.

11. McKillop, A.; Taylor, R. J. K.; Watson, R. J.; Lewis, N. Synthesis, 1994, 31.

12. Scholl, M.; Ding, S.; Lee, C. W.; Grubbs, R. H. Org. Lett. 1999, 1, 953.

13. Garber, S. B.; Kingsbury, J. S.; Gray, B.L.; Hoveyda, A. H. J. Am. Chem. Soc. 2000, 122, 8168.

14. Rivard, M.; Blechert, S. Eur. J. Org. Chem. 2003, 12, 2225.

15. (a) Gosh, A. K.; Hussain, K. H. Tetrahedron Lett. 1998, 39, 1881. (b) Fürstner, A.; Langemann, K. J. Am. Chem. Soc. 1997. 119. 9130.

16. For a recent review on Selectfluor: Nyffeler, P. T.; Duron, S. G.; Burkart, M. D.; Vincent, S. P.; Wong, C.-H. Angew. Chem. Int. Ed. 2005, 44, 192.

17. Liu, J.; Wong, C.-H. Tetrahedron Lett. 2002, 43, 4037.

18. Bassindale, A. R.; Stout, T. Tetrahedron Lett. 1984, 25, 1631.

19. (a) Hong, S. H.; Sanders, D. P.; Lee, C. W.; Grubbs, R. H. J. Am. Chem. Soc. 2005, 127, 17160. (b) Bourgeois, D.; Pancrazi, A.; Nolan, S. P. ; Prunet, J. J. Organomet. Chem. 2002, 643-644, 247.

20. For this reaction, the exact positioning of the double bond after cross-coupling is illdefined [mixtures of products]. This reaction was not optimized as syn-12 could not be obtained analytically pure in sufficiently large amount after silica gel purification.

21. Further work is required to investigate in detail the factors that influence the product outcome of these metathesis couplings. One solution to prevent double bond isomerization is the use of 1,4-benzoquinone [see reference 19(a)]. 